\title{
Social E-Enterprise:
}

Value Creation through ICT

\author{
Teresa Torres-Coronas \\ Universitat Rovira i Virgili, Spain \\ Maria-Arantzazu Vidal-Blasco \\ Universitat Rovira i Virgili, Spain
}


Managing Director:

Editorial Director:

Book Production Manager:

Publishing Systems Analyst:

Development Editor:

Assistant Acquisitions Editor:

Typesetter:

Cover Design:
Lindsay Johnston

Joel Gamon

Jennifer Yoder

Adrienne Freeland

Myla Merkel

Kayla Wolfe

Henry Ulrich

Nick Newcomer

Published in the United States of America by

Information Science Reference (an imprint of IGI Global)

701 E. Chocolate Avenue

Hershey PA 17033

Tel: 717-533-8845

Fax: 717-533-8661

E-mail: cust@igi-global.com

Web site: http://www.igi-global.com

Copyright (C) 2013 by IGI Global. All rights reserved. No part of this publication may be reproduced, stored or distributed in any form or by any means, electronic or mechanical, including photocopying, without written permission from the publisher. Product or company names used in this set are for identification purposes only. Inclusion of the names of the products or companies does not indicate a claim of ownership by IGI Global of the trademark or registered trademark.

\section{Library of Congress Cataloging-in-Publication Data}

Social e-enterprise: value creation through ICT / Teresa Torres-Coronas and Maria-Arantzazu Vidal-Blasco, editors.

p. $\mathrm{cm}$.

Includes bibliographical references and index.

Summary: "This book provides research on the understanding of ICT in the social enterprise field as it emerges as a major component of both business models and developed economy"--Provided by publisher.

ISBN 978-1-4666-2667-6 (hbk.) -- ISBN 978-1-4666-2698-0 (ebook) -- ISBN 978-1-4666-2729-1 (print \& perpetual

access) 1. Social entrepreneurship. 2. Social responsibility of business. 3. Nonprofit organizations--Information technology. 4. Information technology--Social aspects. I. Torres-Coronas, Teresa, 1966- II. Vidal-Blasco, Maria-Arantzazu, 1970HD60.S5846 2013

658.4'038--dc23

2012029181

British Cataloguing in Publication Data

A Cataloguing in Publication record for this book is available from the British Library.

All work contributed to this book is new, previously-unpublished material. The views expressed in this book are those of the authors, but not necessarily of the publisher. 


\title{
Chapter 1 \\ Social and Solidarity Economy Web Information Systems: State of the Art
}

\author{
Mariana Curado Malta \\ Algoritmi Center, University of Minho, Portugal \\ Ana Alice Baptista \\ Algoritmi Center, University of Minho, Portugal
}

\begin{abstract}
This chapter presents the state-of-the-art on interoperability developments for the social and solidarity economy web based information systems. A search on the bibliographic databases showed that there are no articles on interoperability initiatives on the social and solidarity economy, so it was necessary to have other sources of information: a preliminary analysis of the platforms that support social and solidarity economy activities; and interviews with the representatives of some of the world's most important social and solidarity economy organizations. The study showed that the platforms are still not interoperable, but that there are efforts in this direction promoted by the social and solidarity economy organizations. It is clear that these organizations will need to find a common framework of understanding in order to implement interoperability among their platforms.
\end{abstract}

\section{INTRODUCTION}

The Social and Solidarity Economy (SSE) can be broadly defined as a type of economy in which the goals are different either from the ones of the marketeconomy or from the state's (Lechat, 2007).
Allegedly, these goals are neither centered in profit nor in individualistic needs. It is an economy that presents itself as a material and human alternative to capitalist economy (Cattani, Laville, Gaiger \& Hespanha, 2009).

Social and solidarity economy organizations are composed of self-organized communities (e.g.

DOI: 10.4018/978-1-4666-2667-6.ch001

Copyright (c) 2013, IGI Global. Copying or distributing in print or electronic forms without written permission of IGI Global is prohibited. 
geographical or sectorial). These organizations have machine-to-machine communication needs that are internal or external to them, for example to other kind of organizations like governmental organizations. In order to support these machineto-machine communication needs, there is the need to provide interoperable solutions among the software platforms that support their activities.

According to the Dublin Core Metadata Initiative Glossary (Woodley, 2005), interoperability is the ability of different types of computers, networks, operating systems, and applications to work together effectively, without prior communication, in order to exchange information in a useful and meaningful manner.

As we are talking about exchange of information between machines (software), full compliance with international standards is essential.

The objective of this chapter is to draw the state-of-the-art on interoperability developments for the SSE area. This is part of the first phase of a larger project which aims to define an interoperability framework for the SSE. The search on bibliographic databases revealed no initiatives of interoperability between SSE platforms, so it was necessary to replace the literature review with two other sources of information: 1) Preliminary analysis of the platforms that support SSE activities; and 2) Interviews with the representatives of some of the world's most important SSE organizations. They showed that, in fact, the platforms are still not interoperable, but that there are efforts in this direction promoted by these organizations.

This article begins with this introduction, followed by a contextualization section in which the concepts of SSE and semantic interoperability are explained in more detail. The third section explains the methodology used for each of the tasks carried out in defining the state-of-the-art on interoperability developments for the SSE. The following section presents the state-of-the-art mentioned above. The article ends with the conclusions and future work, followed by the acknowledgments and references.

\section{BACKGROUND}

\section{The Social and Solidarity Economy}

The SSE reported in the literature as the "other economy" is a third way, distinct from the market economy and the central state power. It boils down in a pragmatic way to the union or association of people with a common purpose for the group and the society around them, where new values are born in opposition to practices of the capitalist world that are considered predatory. The SSE is characterized by solidarity and equality, the collective ownership of the work and its nonalienation (Cattani et al., 2009). The concepts of Social Economy and Solidarity Economy are quite similar but yet different, and because they are used by the organizations we studied to define themselves, we will detail them and their differences.

In the Social Economy the stress lies, as Cattani et al. (2009) stated, on the "search for an economic democracy associated to social utility" (p. 156). The Social Economy was born to solve social problems that the state did not manage to solve. This form of economy has its prehistory in the most remote human associations in Egypt, Greco-Latin antiquity, the MiddleAges in Europe, Imperial China or Pre-Columbian America. These were systems of mutual support, both professional and religious or artistic. Currently sociologists characterize the social economy in two ways: one from the standpoint of identifying the main legal and institutional forms found (cooperatives, mutual societies, associations and foundations); the other by identifying the common features of companies and organizations (secondary profit, management autonomy, democratic control, the primacy of people and of the social object over the capital upon the distribution of surpluses) (Lechat, 2007).

On the other hand, Solidarity Economy is a concept broadly used in several continents, with varied meanings all around the idea of solidarity (Cattani et al., 2009). This concept spread at the 
beginning of the nineties with the appearance of many initiatives of citizens that gathered according to the "principles of cooperation, autonomy and democratic management" (p.162). In peripheral countries this association of workers arose as an alternative to capitalist society, and a way to survive to poverty and exclusion, adding values of native practices, making the community feeling prevail; it embraces also ecological, sustainable development, rights and duties of citizens, gender equality and respect for individuality and cultures worries. Solidarity Economy is characterized by solidarity and equality, by the collective ownership of work. It is based on the idea that those having no capital are not necessarily less able and have therefore the right to perform more complex and less alienating tasks.

Most of the people involved in the Solidarity Economy believe that they have a mission to change society in order to promote democracy, and to look for benefits for the whole and not just for the individual. The Solidarity Economy brought to the public debate notions of social utility and collective interest (Laville, 1994) while in social economy there are no such concerns or such explicit awareness. In fact, Solidarity Economy brings the socio-political dimension to the economy.

Solidarity Economy and Social Economy involve, together, a large number of citizens throughout the world that search, more or less consciously, to build a different paradigm for economy. In this study, we will use the acronym SSE to refer to this large group of citizens that form the Social and Solidarity Economy.

\section{SSE Organizations and Structure}

Nowadays SSE is an important part of the economy. More than ever, some countries or governments stress its importance in the fight against poverty and in human development. For that reason they included in their programs policies that support the SSE. As Schiochet (2009) states, some governments have "actions that go deeper under the point of view of the action in itself and the internal consensus with relation to Solidarity Economy, when in others, actions are more seldom and residual" (p. 57).

Currently, $10 \%$ of the world population is organized in cooperatives with ties to the International Cooperative Alliance ${ }^{1}$, what corresponds to a value between 600 and 700 million people (Singer, 2008). The European Parliament launched a resolution concerning Social Economy in society and the need to create politics of support and framing (Parliment, 2009). However, the best examples to report are Brazil, Luxembourg and France. Brazil, with Lula's government (2003-2010), created a specific Secretary of State for the SSE (Secretary of State of the Solidarity Economy). It is now the country where SSE is officially more meaningful (Singer, 2008). Recent studies, like the one of Singer and Schiochet (2006) reveal the existence of 15,000 enterprises of Solidarity Economy in Brazil, in 2005, having this value increased to 22,000 in 2008 (Singer, 2008). In Luxembourg a secretary of state for the Solidarity $^{2}$ was appointed and in France, in the newly inaugurated government of François Hollande (2012), there is a secretary of state for social and solidarity ${ }^{3}$ economy.

As it was stated before, SSE is made up of groups of people, associations, cooperatives or mutual benefit societies. This diversity of organizations, although considered vital to their strengthening, can bring some complexity to the cooperation among them. Currently there is a mix of social movements, networking organizations or chains of production that give SSE an extraordinary dimension. Networking integration is one of equal elements whose purpose is the possibility of profit in the scale of production and in the homogenization of production and commercialization (FBES, 2008). Besides, it's not only about economic integration, but also about the establishment of economic ties based on the basic and fundamental principles of relationship 
between SSE organizations. The existence of commercial relations does not imply the integration in a network, the network is characterized by the ties that are established (FBES, 2008).

The networking structure exists at local, national, international, and even sectorial level and makes it possible for the organizations to have access to strategies of action and resource sharing, enabling displacements in the social structure (Cattani et al., 2009). This is particularly important in SSE because through networking people have more power, more opportunities and social visibility, they develop namely relationships of exchange of goods or services (room for sharing and for personal and organizational strengthening) and cooperative agendas ${ }^{4}$.
The types of networking relations existing in SSE are varied and depend much on the country where they operate. Figure 1 shows a representation of SSE organizations articulating locally, i.e. organizing themselves in local SSE platforms.

Figure 2 shows examples of possible relations at national or international level. They are national meeting points, where local platforms (local organizations that elect their representatives) are represented in local, regional, national and/or international events and platforms (depending on the size of the country). There are also sectorial networks that organize themselves in a dimension of affinity: cotton producers, corn producers, careers of elderly, for example (Scherer-Warren, 2006).

Figure 1. SSE local networks and productive chains. (Source: Own elaboration)

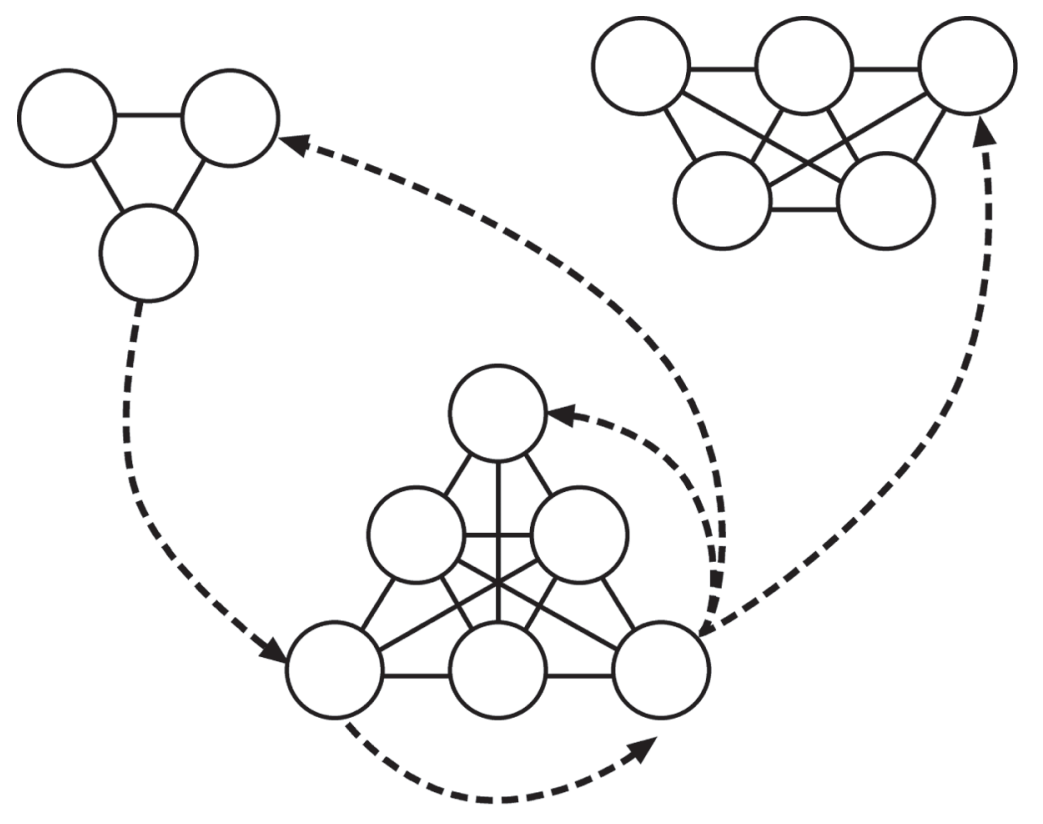

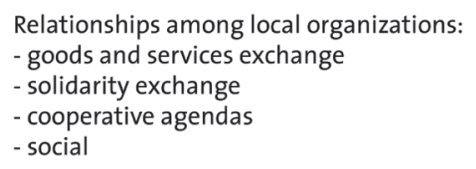

Relationships among local organizations: - goods and services exchange

- solidarity exchange

- cooperative agendas

- social

productive chain

Local organization (Cooperative, association, people or groups of people informally organised, etc) 
Figure 2. SSE sectorial, regional, national, and international networks. (Source: Own elaboration)

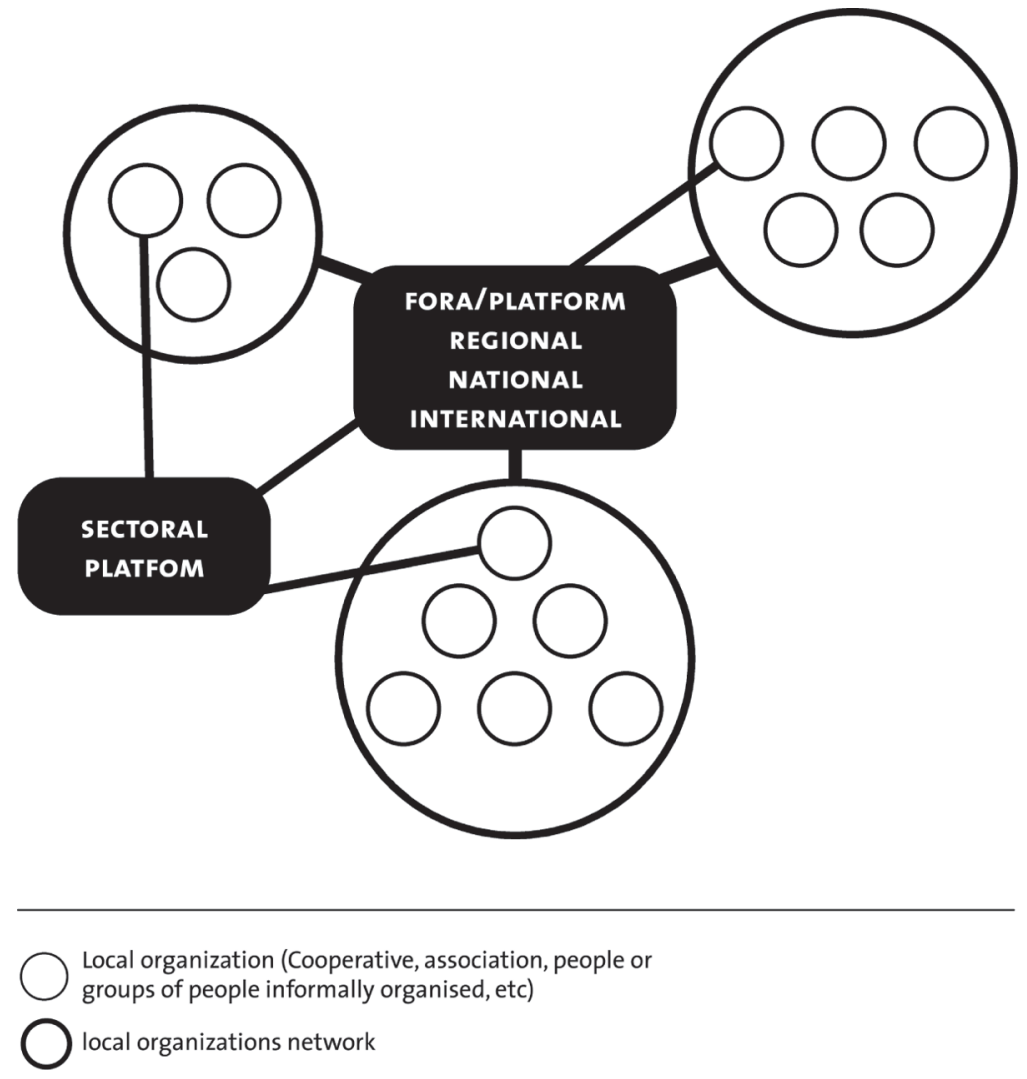

The organization of these meeting points is somewhat replicated in the SSE Web Information System (WIS). These WIS support the organization of these networks giving them a high visibility, potentiating the relations and transactions, and enabling the creation of new relationships. In some cases these relationships would be unthinkable without the existence of these systems due to geographical distances. These platforms gather in the Intercontinental Network for the promotion of the Social Solidarity Economy ${ }^{5}$ (RIPESS), a world place for promoting the SSE.

\section{Web Based Information Systems for SSE}

WIS are information systems that are based on web technology. They can be integrated or not in common Information Systems (IS). WIS may be classified in different kinds of systems, such as intranets, web sites to interact with consumers and e-commerce sites to sell products and services (Yang and Tang, 2003). WIS have a strong impact on business as well as people's lives (Wang, 2001). They enhance competitiveness of organizations, since they can lower transaction costs (e.g. communications) and they allow organizations to focus on target groups through the use of marketing tools, customer relationship management systems and social web tools.

Normally the number of users of a WIS is unknown since the extranet part of the WIS can be available to the whole world. This can be a problem for the requirements engineers since it is very difficult to define stakeholders. However, they are powerful tools for the dissemination of information and enlarge the organizations' domain of action to the world. 
In order for SSE WIS to fully replicate the networking structure of SSE organizations and operate globally, they need to share information and communicate with each other and with external non-SSE WIS. To do so, they need to be interoperable, i.e. they need to comply to and share among themselves and with external WIS a number of standards, protocols and rules that range from some that are community specific to others that are worldwide applicable.

\section{Interoperability}

There are several approaches to interoperability. For the sake of this article, we will focus on the definitions which are directly related to it. For more information about interoperability see, for example, IEEE (2010), IDABC (2004) and Payette, Blanchi, Lagoze and Overly (1999).

In the context of Information Technologies interoperability can be defined as the possibility of multiple systems, with different kinds of software or hardware, and different data structures and interfaces, to exchange data without previous communication, with the minimum loss of contents and functionality (Press, 2004).

The Dublin Core Metadata Initiative (DCMI) defines interoperability in its glossary Woodley (2005) as:

The ability of different types of computers, networks, operating systems, and applications to work together effectively, without prior communication, in order to exchange information in a useful and meaningful manner.

Semantic interoperability focuses on meaningful exchanges of information, i.e. the information has the same interpretation (or very closely) by both the sender and the receiving systems. Our work takes place under this perspective.

\section{METHODOLOGIES}

We intended to conduct a literature review about interoperability on SSE WIS, performed an analysis of these platforms and made a series of interviews to their community leaders. This section presents in detail the methodologies we used on each of these steps.

\section{Literature Review}

In the first part of the bibliographic search we have done general searches and then more specific searches in on-line databases: Google Scholar ${ }^{6}$, ISI Web of Knowledge ${ }^{7}$, SCI ETD Networked Digital Library of Thesis and Dissertations ${ }^{8}$, Scopus $^{9}$ and Oaister ${ }^{10}$.

Four different main lines of basic searches were made: on SSE, on Interoperability, on Web based Information Systems and on Interoperability for the Social and Solidarity Economy.

These searches were made in English, in Portuguese and Spanish. The former because it is the main language used in scholarly communication, the latter two because they are languages were the SSE is developed the most in the world (Latin America, in particular Brazil) (Singer \& Schiochet, 2006).

A central set of articles was selected, but no article was found that had a reflection or study on the specific aspect of interoperability for the SSE.

In the second phase of the search the references of the selected set of articles were analyzed, allowing us to select new articles by relevance of title and abstract. Then an iterative process was implemented in what the new articles were concerned, finishing the process when were no new article being referenced.

In the third and last phase of the search process, new articles were selected when they would refer the central set of articles kept in phase 1. These 
new articles were chosen following the same criteria as in phase 2 .

The articles selected were used to draw the contextualization, but not the topic itself as we could not find any articles on interoperability initiatives on the SSE area.

\section{Analysis of SSE WIS and Interviews}

The RIPESS was the starting point for our study. RIPESS has a website with a list of all the websites and WIS of the SSE networks in the world. It should be noted that in spite of SSE initiatives in all five continents, only a small number of organizations are registered in a WIS. It should also be highlighted that the fact that there are no WIS for some continents or countries it doesn't mean that in these continents or countries the SSE is not organized in the field or doesn't have non-WIS software platforms to support it; it means that for some reason (organizational, political, economical or other) an Internet support tool was not yet implemented. It is not the objective of this work to explain the reasons for this fact.

The process had two phases. In the first phase we did a preliminary study based on a set of WIS chosen from the RIPESS website. This choice followed the criteria:

- At least one website per region;

- Having more than one website in the region, the ones selected had to have at least some of the following defined functionalities: Themes, Events, News, Blog, Social Network, Catalog, e-commerce, Tags, RSS feeds, Metadata.

The results of this preliminary analysis may be accessed on the link http://www.maltas. org/1stphase.pdf.

Based on these results, we selected for an exploratory analysis the WIS that were the most developed in terms of the functionalities described
Table 1. List of the SSE WIS studied

\begin{tabular}{|l|l|l|}
\hline \multicolumn{1}{|c|}{ Country } & \multicolumn{1}{|c|}{ Organization } & \multicolumn{1}{c|}{ WIS URI } \\
\hline Austria & Vivir Bien & $\begin{array}{l}\text { http://vivirbien. } \\
\text { mediavirus.org }\end{array}$ \\
\hline Brazil & $\begin{array}{l}\text { Forum Brasileiro } \\
\text { da Economia } \\
\text { Solidária }\end{array}$ & $\begin{array}{l}\text { http://www.ciran- } \\
\text { das.net }\end{array}$ \\
\hline Brazil & Solidarius & $\begin{array}{l}\text { http://www.soli- } \\
\text { darius.com.br }\end{array}$ \\
\hline Canada (Québec) & $\begin{array}{l}\text { Chantier de } \\
\text { l'Économie } \\
\text { Sociale }\end{array}$ & $\begin{array}{l}\text { http://www.econo- } \\
\text { miesocialequebec. } \\
\text { ca } \\
\text { http://www.achet- } \\
\text { ersolidaire.com }\end{array}$ \\
\hline France & $\begin{array}{l}\text { Mouvement } \\
\text { pour l'Économie } \\
\text { Solidaire }\end{array}$ & $\begin{array}{l}\text { http://www.la- } \\
\text { bdis.org }\end{array}$ \\
\hline Italy & $\begin{array}{l}\text { Fondazione Cul- } \\
\text { turale Banca Etica }\end{array}$ & $\begin{array}{l}\text { http://www.zoes.it } \\
\text { http://www.buon- } \\
\text { mercato.org }\end{array}$ \\
\hline Luxembourg & $\begin{array}{l}\text { Institut Européen } \\
\text { de l'Économie } \\
\text { Solidaire }\end{array}$ & $\begin{array}{l}\text { http://www.eco- } \\
\text { solux.lu }\end{array}$ \\
\hline Spain & $\begin{array}{l}\text { Red de redes de } \\
\text { Economía Alter- } \\
\text { nativa y Solidaria } \\
\text { (REAS) }\end{array}$ & $\begin{array}{l}\text { http://www.econo- } \\
\text { miasolidaria.org }\end{array}$ \\
\hline
\end{tabular}

previously. Table 1 lists the SSE WIS that were object of our study.

We additionally conducted an interview to each of the representatives of the organizations listed in Table $1^{13}$. All the interviews were done through Skype, and their main objectives regarding WIS were:

- To identify the WIS that support these organizations;

- To understand how these WIS work through the point of view of their creators;

- To do an exploratory study of the organizations interoperability needs.

Six (6) interviews were conducted (see Table 2) and all of them were recorded and transcribed (see Table 3). These interviews were semi-directive as they were adapted to the characteristics and 
Table 2. List of the interviewees

\begin{tabular}{|l|l|l|}
\hline \multicolumn{1}{|c|}{ Interviewee } & \multicolumn{1}{|c|}{ Country } & \multicolumn{1}{c|}{ Organization } \\
\hline Agnès Gyolaia & Luxembourg & $\begin{array}{l}\text { Institut Européen } \\
\text { de l'Économie } \\
\text { Solidaire }\end{array}$ \\
\hline Carlos Rey & Spain & $\begin{array}{l}\text { Red de redes de } \\
\text { Economía Alter- } \\
\text { nativa y Solidaria } \\
\text { (REAS) }\end{array}$ \\
\hline $\begin{array}{l}\text { Florian Lederm- } \\
\text { man }\end{array}$ & Austria & Vivir Bien \\
\hline Jason Nardi & Italy & $\begin{array}{l}\text { Fondazione Cul- } \\
\text { turale Banca Etica }\end{array}$ \\
\hline Marc Alphandery & France & $\begin{array}{l}\text { Mouvement } \\
\text { pour l'Économie } \\
\text { Solidaire }\end{array}$ \\
\hline Nancy Neamtan & Canada (Québec) & $\begin{array}{l}\text { Chantier de } \\
\text { l'Économie } \\
\text { Sociale }\end{array}$ \\
\hline
\end{tabular}

experiences of the interviewee. The interviewees received the script ${ }^{14}$ by email some weeks before the date of the interview. Some of them emailed back some answers before the interview.

\section{WEB BASED INFORMATION SYSTEMS FOR THE SOCIAL SOLIDARITY ECONOMY: STATE OF THE ART}

\section{Analysis of SSE WIS and Results of the Interviews}

In the following section we will inform about the most advanced WIS in the world. They are the Internet "show room" of the organizations in their countries.

\section{Austria: Vivir Bien}

The case of Austria is a very particular one because Austria is a country where the social state is very strong. The SSE is defined outside the status quo of society. The Vivir Bien interviewee says:
(...) I would say in Austria the tradition is that the state is much more involved, because we have a strong Social Democrat tradition so the tradition is that the state itself is much more involved actually in these things and we don't really have this tradition of social economy as really independently embedded in the economy(...) (Florian Ledermman (Interviewee), 2011)

The "Vivir Bien" WIS is built by a group of people, informally organized, that volunteered to manage the system. They do not represent any formal organization and they don't own any label of SSE. This informality is present in all aspects of this project since there are no goals to achieve. Anyone (person, group of people, organization, and initiative) is free to join "Vivir Bien" as long as they receive an invitation from an user already registered in the system (to control SPAM). The interviewee, Flo Ledermman, presents "Vivir Bien" as a set of resources that can be added by any user without any limitation or control. A resource can be anything, i.e. a market, a shop, or bread offered in a bakery. Every resource has information about it, with no limits for the information one wants to introduce. These resources are mapped with geographical information. The WIS is then a set of resources with information, mapped and organized in themes. The interviewee presents the logic that is behind the development of the system:

Table 3. Interviews: URL transcripts and audio files

\begin{tabular}{|l|l|}
\hline \multicolumn{1}{|c|}{ Interviewee } & \multicolumn{1}{c|}{ Transcription } \\
\hline Agnès Gyolaia & http://hdl.handle.net/1822/18426 \\
\hline Carlos Rey & http://hdl.handle.net/1822/18425 \\
\hline Florian Ledermman & http://hdl.handle.net/1822/18427 \\
\hline Jason Nardi & http://hdl.handle.net/1822/18420 \\
\hline Marc Alphandery & http:/hdl.handle.net/1822/18424 \\
\hline Nancy Neamtan & http://hdl.handle.net/1822/18422 \\
\hline
\end{tabular}


(...) we use it in the same way as semantic Web, we use it as statements as triples, you know, you have the resource and you have the predicate and you have an object, as it is really the same. So really the tags, in my opinion, I mean, tags is a bad word, because it is used with a different meaning. (...) our tags are more sophisticated, they have a key and the values, they are really statements. (Florian Ledermman (Interviewee), 2011)

\section{Brazil: Cirandas}

The "Forum Brasileiro para a Economia Solidária" is the responsible for the WIS "Cirandas". This WIS is built upon Noosfero ${ }^{15}$, an open source software specifically developed for the Solidarity Economy in Brazil. This WIS has 4789 individual users, 21859 organizations/initiatives/enterprises and 360 communities of $\mathrm{SSE}^{16}$. As Noosfero implements social networks, all these communities were naturally created in a way that mimics the real networks in the field. It is, however, important to note that new virtual networks were established due to the online presence of these communities - those reinforce even more SSE in Brazil. The functionalities of "Cirandas" are: blog, private and public chat, networks (of people, communities and organizations or initiatives or enterprises). Each "Cirandas" organization, initiative, enterprise and community user has a show page of their own products and services (a kind of a catalog but with no e-commerce functionality) and another page to show the location (in a Google map) of the physical shops of the organization.

Every user of "Cirandas" can self-define within a list of themes. Through the use of a search tool it is possible to find theme partners for a productive chain or for a social network (e.g. political affinities).

Cirandas is a very powerful tool to promote the SSE Brazilian organizations and networks.

\section{Brazil: Solidarius}

The Solidarius WIS is maintained by a selforganized social economy initiative and it is open to any world citizen interested in developing SSE initiatives. Solidarius allows users to implement social economy enterprises, collaborative networks, community banks, to sell and buy products or services within the system, to implement cooperatives and to implement groups with social currency exchanges. A social currency exchange is a concept created by the Solidarius project. To know more about it sees (Mance, 2008).

Solidarius has a few extra functions with respect to the other portals described. These functions implement a kind of "economic intelligence" and they are: the analysis of value exchanges and network (consumption / production), the "business" plan with SSE criteria, and the Solidarity Interchange System (SIS - Sistema de Intercambio Solidário) which has a "value representation". This is a very particular system, unique in the world. According to Solidarius (2011):

"Each member of the Solidarius community has a credit account Solidarius that enables the user to make local or international exchanges of products and services. The value of items exchanged is measured in Solidarius credits. The items offered can be seen in the window of the SIS. Solidarius Credits are generated by the users, being associated to the donations made by them to a World Fund for Solidarity Economy, which is organized by the National Sections. The record of these donations is made by the operator of the National Section of the Fund receiving the donation. This operator is elected by the participants in each country. The Fund is self-managed by the Community itself and has direct democracy mechanisms provided by Solidarius. All transactions are recorded electronically and these records are accessible to all participants, ensuring full transparency to the system." 


\section{Canada: Economie Sociale Québec}

The "Chantier pour l'Économie Sociale" is the organizations in charge of the WIS "Économie Sociale Québec". This WIS is organized by activity sector where each sector has common elements: texts, documents, profiles, blog, news, job offers and products and services. The products and services are browsed but the selling is done in another WIS specially developed for e-commerce, the "Acheter solidaire" WIS.

The new users are accepted through their juridical status, and when they have doubts about the suitability of a certain new user, they contact the local/regional "Chantier" offices in order to have more information on the organization that is being accepted.

The WIS "Économie Sociale Québec" is a system to support the organizations activities. Users can upload documents, create news and events. There is also an organization mapping with geographical information.

The "Chantier" also made the political choice of defining a different website for the e-commerce functionality. This e-commerce portal has the particularity of having a bank of offers and requests concerning products or services that can be posted by users.

\section{France: La BDIS}

The "Mouvement pour la Économie Solidaire" (MES) is the organization that implemented and maintains the WIS La BDIS. This WIS maps all the Solidarity Economy organizations in France, but not the Social Economy organizations, since MES is an "umbrella" organization of only the Solidarity organizations in France. La BDIS does not support the activity of these Solidarity organizations. Each organization is identified in a map and has its own profile available. MES has a criterion to accept its member organizations. This criteria has to do with identity, values of the
SSE and compromises, the last issue is a rather political one.

In France there are different "umbrella" organizations that group the Social Economy organizations, though the French Social Economy organizations are not mapped in La BDIS and they are neither a member of the RIPESS. This has to do with the "umbrella" organizations and its political choices.

MES built a chart of principles which has to be signed by every new organization that wants to enter La BDIS. This WIS has only available as information the profile of the users, allowing organizations to see the mapped SSE organizations but there are no other tools for networking. There is also an organization mapping with geographical information

It is interesting to note that there are several e-commerce sites in France that sell SSE products. The interviewee refers a particular e-commerce website: Eco- Sapiens ${ }^{17}$. The webmaster of this e-commerce website was contacted by email and confirmed this information. He added that Ecosapiens exchanges data automatically with the suppliers through XML technology.

\section{Italy: Zoes}

The WIS "Zona Equosostenible" (ZOES) is a portal for social networks, geographic referencing and thematic on SSE in Italy. This WIS was created and is maintained by the "Fondazione Culturale Banca Etica". ZOES supports the organizations activities which are registered in the platform. To become part of ZOES, new organizations must be certified by the Italian agency that gives the SSE stamp and must be recommended by one organization already registered in ZOES. Besides, the new organizations must go through a sorting process, through the filing of an on-line form. In this form, the 5 first questions are crucial to be accepted in ZOES since if the new organization answers "no" to one of these 5 questions it will be immediately rejected by ZOES. We note that 
there is very specific information concerning SSE on this WIS, it has to do with: certifications and recognitions of the organizations; their network inside the system; the possibility to define themselves as experts in a certain field which will allow to be directly contacted by a consumer or other organizations to look for expertise inside the network.

This WIS is complemented by an e-commerce portal, which besides all the common functionalities of an e-commerce site (sell services and products) has specificities to SSE such as: the "transparent price" which is a way for a consumer to know the parcels of any product's price (parcel of production, logistics, etc.); and an emphasis on the good practices of the producer (environment, labor, etc.) which are clearly shown on the page of the product. It is interesting to note that it was a political choice to separate ZOES from the ecommerce activities.

Besides selling products and services through Buon Mercato, ZOES is a working space for SSE promotion. There is a set of functionalities which are cataloged in ten different themes. These functionalities are: job offers, edited books, documents, links to organizations which are cataloged on this thematic, news, events and forum. There is also an organization mapping with geographical information.

The wish to share information with the world SSE community on thematic and the organization's information is clearly stated by the interviewee:

"My idea is that, both in Italy and internationally, we should start sharing the information we have inside, naturally being careful of having the authorization of the users. So the content, when the users register they know, and we have it also in our policy, which is in the terms of use and the principles which are bellow at the end, and also in the instructions on how you use ZOES on the top. In principle it is all open content, creative commons, so we expect, if it is on the Internet and its public profile, we expect that that content can be shared.
(...) this is a user content platform, as you can see below the footer, before saying who promotes it, there are 10 colored buttons and these are the 10 themes in which ZOES is thematically divided (...) we want to share that! Each of these has RSS and even the profiles have its own RSS and can be replicated in any other Web site. But the idea of the project we are doing with RIPESS is that we will be able to share information with common filters, so that it is comparable information, not just copy that information, but you can compare and work on it and to find information, to aggregate information etc. (...)." (Jason Nardi (Interviewee), 2011)

\section{Luxembourg: Ecosolux}

The "Institut Européen de l'Economie Solidaire" created the WIS ECOSOLUX with the aim of developing the Solidarity Economy in Luxembourg. In this WIS there are initiatives and organizations that are selected by a piloting committee. This committee analyses the forms new candidates fill on the WIS and accepts them in regular meetings held in Luxemburg. The organizations profiles can be updated by the organizations or initiatives as soon as they have access to the WIS. News and events are introduced by the WIS webmaster and there is no tool for the networking of organizations registered on ECOSOLUX.

\section{Spain: Economía Solidaria}

The "Red de redes de EconomíaAlternativa y Solidaria" (REAS) is a Spanish network of networks which is organized by region. This organization is responsible for the WIS "Economía Solidaria". To be part of this WIS the organizations have to be registered in a local/regional REAS.

This WIS has the particularity of having sheets of "good practices" (environmental, economical, etc.) with text and multimedia information, produced by the organizations, in order to share knowledge and experiences. 
The users of this WIS can update their profile, introduce information (news, documents, bibliography and videos) and tag them. The interviewee noted that tags are very ambiguous and that they have a lot of work organizing them. There is also an organization mapping with geographical information.

The interviewee also said that there is some data exchange (news cataloged in tags) between the Economía Solidaria Portal and the Brazilian WIS "Cirandas" and the site REAS of Latin America and Caribbean. This is done through RSS feeds which are also organized with tags.

\section{Interoperability on the SSE WIS}

In 2010 RIPESS has created a task-force for the development of interoperability among its members' WIS. This is a pilot project that RIPESS intends to enlarge as soon as new countries have WIS with conditions to join. The members of this task-force have been sharing information in an informal way in the past, and they committed to map the SSE organizations in each country as a first step for a world mapping. The main goals for this interoperability are:

- More visibility: this visibility has distinct levels:

- Final Consumers: They can buy products issued in the SSE economy; they become aware of the state-ofthe-art of SSE;

- Governments: They become aware of the world dimension of SSE and have access to statistics and global information;

- Bigger network dimension: what was local becomes global, the world dimension is powerful and can strengthen SSE.

In March 2011 this task-force met in Paris for the first formal meeting. They met again in October 2011, in the World Forum for the SSE ${ }^{18}$, held in Québec, Canada. Again they have stressed their goal of strengthening their networks (that have been existing in the field for some years) using interoperable WIS, sharing semantics.

Today, technological leaders of this task-force are aware that they need both an internal (nationally) and external (internationally) organization, in order to have the same interpretation (or very closely) by all the members, to allow meaningful exchanges of information among their WIS. It is obvious that they will need to find a common framework of understanding.

The task-force is just beginning this work and they are just taking the first steps on the worldwide road of (semantic) interoperability.

\section{FUTURE RESEARCH DIRECTIONS}

For future research, we will follow up the work underway on the RIPESS community regarding interoperability, and will monitor its development. We are specifically interested in following up the methodology that the RIPESS task-force will be using and assess its results. Also, a deeper study on the RIPESS interoperability needs will be done, by studying in detail the interviews using qualitative analyses software.

We are also going to develop a state-of-the-art study on metadata Application Profiles (AP), in order to understand: what are the most used base standards or schemas in the metadata community; what are the type of communities that developed those AP; what are the used controlled vocabularies (especially those with $\mathrm{RDF}^{19}$ binding schemas) and; what are the AP that have developed binding schemas with the RDF semantic $\mathrm{Web}^{20}$ standard technology. We are also especially interested in the study of the methodologies used to develop the AP of our state-of-the-art study.

One of the outcomes of this research work will be a Dublin Core Application Profile for the SSE community. With this Dublin Core Application Profile the SSE community will be able to interoperate among itself but also with partners outside their community. 


\section{CONCLUSION}

The SSE world community constitutes a very particular case of economy, it is in fact more than economy: networks are created and information exchanged - beyond the normal commercialization of products or services - with care and respect for the other, for the society and the planet. Their presence on the Internet is supported by specific SSE WIS platforms that in some ways replicate the physical networking organization. However, to do it fully, these platforms need to be interoperable.

The objective of this chapter was to draw the state-of-the-art in what concerns interoperability, especially semantic interoperability, on SSE platforms. The searches on bibliographic databases revealed that there is no literature in the field so far. The analysis of the SSE WIS revealed that there are some connections between platforms but that they are still very incipient (e.g., through RSS feeds) and the interoperability is very rudimentary if existing at all. The interviews to the WIS technological leaders revealed that SSE organizations are very interested in the topic and that they have, inclusively, started to do some work on it, although not yet published.

\section{ACKNOWLEDGMENT}

We would like to thank all the members of the RIPESS task-force for sharing with us their insights, and for letting us be part of the team as observers. We would like also to thank Ida Cruz for all the drawings of this article.

\section{REFERENCES}

Cattani, A. D., Laville, J.-L., Gaiger, L. I., \& Hespanha, P. (2009). Dicionário internacional da outra economia (p. 346). CES.
FBES. C. de l'Économie S. (2008). Ousar solidariedade: Partilhas e práticas de economia social e solidária no Brasil e no Quebec. (p. 114). FBES and Chantier de l'Economie Social.

Florian Ledermman (Interviewee). M. M. (Interviewer). (2011). RIPESS interviews - Transcription. Retrieved from http://hdl.handle. net/1822/18427

IEEE. (2010). Standards glossary. Retrieved http://www.ieee.org/education careers/education/standards/standards_glossary.html

Initiative, D. C. M. (2005). DCMI Glossary. Retrieved from http://dublincore.org/documents/ usageguide/glossary.shtml

Jason Nardi (Interviewee). M. M. (Interviewer). (2011). RIPESS interviews - Transcription. Retrieved from http://hdl.handle.net/1822/18420

Laville, J. L. (1994). L'Economia Solidaire - Une perspective internationale. Desclee de Bouwer.

Lechat, M. P. (2007). Economia social, economia solidária, terceiro setor: Do que se trata? CivitasRevista de Ciências Sociais, 2(1), 123-140.

Mance, E. A. (2008). Constelação solidarius: As fendas do capitalismo e sua superação sistêmica. IFiL (pp. 125-144). IFIBE.

Parliment, E. (2009). European parliament resolution of 19 February 2009 on social economy. Retrieved from http://www.europarl.europa.eu/ sides/getDoc.do?type $=$ TA\&reference $=$ P6-TA2009-0062\&language $=\mathrm{EN} \&$ ring $=\mathrm{A} 6-2009-0015$

Press, N. (2004). Understanding Metadata. National Information Standards.

Scherer-Warren, I. (2006). Das mobilizações às redes de movimentos sociais. Sociedade $e$ Estado, 21(1), 109-130. doi:10.1590/S010269922006000100007 
Schiochet, V. (2009). Institucionalização das políticas públicas de economia solidária: Breve trajetória e desafios. IPEA-Mercado de Trabalho, 40, 55-60.

Singer, P. (2008). Economia Solidária. Estudos Avançados, 22(62), 289-314. doi:10.1590/S010340142008000100020

Singer, P., \& Schiochet, V. (2006). Atlas da economia solidaria no Brasil 2005 (p. 60). SENAES/ MTE Brazil.

Solidarius. (2011). Solidarius. Retrieved from http://www.solidarius.com.br/ajuda/quem_somos.php

Wang, S. (2001). Toward a general model for web-based information systems. International Journal of Information Management, 21(5), 385-396. doi:10.1016/S0268-4012(01)00029-9

Woodley, M. S. (2005). DCMI glossary. DCMI. Retrieved from http://www.dublincore.org/documents/usageguide/glossary.shtml

Yang, H. L., \& Tang, J. H. (2003). A threestage model of requirements elicitation for Web-based information systems. Industrial Management \& Data Systems, 103(6), 398-409. doi:10.1108/02635570310479972

\section{ADDITIONAL READING}

Alonso, J. M., Ambur, O.,Amutio, M. A., Azañón, O., Bennett, D., Flagg, R., ... Sheridan, J. (2009). Improving access to government through better use of the web. W3C Interest Group Note, 12.

Bizer, C., Cyganiak, R., \& Heath, T. (2008). How to publish linked data on the web. Retrieved from http://www4.wiwiss.fu-berlin.de/bizer/pub/ LinkedDataTutorial/

Bizer, C., Heath, T., \& Berners-Lee, T. (2009). Linked data - The story so far. International Journal on Semantic Web and Information Systems, 5(3), 1-22. doi:10.4018/jswis.2009081901
Chan, L. M., \& Zeng, M. L. (2006). Metadata interoperability and standardization - A study of methodology part I. D-Lib Magazine, 12(6). Retrieved from http://www.dlib.org/dlib/june06/ chan/06chan.html doi:10.1045/june2006-chan

Coyle, K. (2005). Managing technology - Understanding metadata and its purpose. Journal of Academic Librarianship, 31(2), 160-163. doi:10.1016/j.acalib.2004.12.010

Cuel, R., Delteil, A., Louis, V., \& Rizzi, C. (2007). The technology roadmap of the semantic web. Knowledge Web.

Fontes, B. (2008). Capital social e terceiro setor: Sobre a estruturação das redes sociais em associações voluntárias. Redes Sociais e Saúde: Novas Possibilidades Teóricas, 49-75.

Guijarro, L. (2009). Semantic interoperability in eGovernment initiatives. Computer Standards \& Interfaces, 31(1), 174-180. doi:10.1016/j. csi.2007.11.011

Heery, R., \& Patel, M. (2000). Application profiles: mixing and matching metadata schemas. Ariadne, 25, 27-31.

Hernández-Pérez, T., Rodríguez-Mateos, D., Martín-Galán, B., \& García-Moreno, M.A. (2009). El uso de metadatos en la administración electrónica española: Los retos de la interoperabilidad. Revista Espanola la de Documentacion Cientifica, 32(4), 67-91. doi:10.3989/redc.2009.4.724

Johnston, P. (2003). Metadata and interoperability in a complex world. Ariadne, 37.

Klischewski, R. (2003). Semantic web for egovernment. Electronic Government, 1059-1060.

Laville, A. E., \& Laville, J.-L. (2004). The third sector in Europe. Cheltenham, UK: Edward Elgar Publishing Limited.

Lee, T. B., Hendler, J., \& Lassila, O. (2001). The Semantic Web. Scientific American, 284(5), 34-43. doi:10.1038/scientificamerican0501-34 
Nilsson, M. (2010). From interoperability to harmonization in metadata standardization. Stockholm, Sweden: Royal Institute of Technology.

Otjacques, B., Hitzelberger, P., \& Feltz, F. (2007). Interoperability of e-government information systems: Issues of identification and data sharing. Journal of Management Information Systems, 23(4), 29-51. doi:10.2753/MIS0742-1222230403

Park, E. G., Lamontagne, M., Perez, A., Melikhova, I., \& Bartlett, G. (2009). Running ahead toward interoperable e-government: The government of Canada metadata framework. International Journal of Information Management, 29(2), 145-150. doi:10.1016/j.ijinfomgt.2008.06.003

Payette, S., Blanchi, C., Lagoze, C., \& Overly, E. (1999). Interoperability for digital objects and repositories. D-Lib Magazine, 5(5), 1082-9873. doi:10.1045/may99-payette

Shadbolt, N., Hall, W., \& Berners-Lee, T. (2006). The semantic web revisited. Intelligent Systems, IEEE, 21(3), 96-101. doi:10.1109/MIS.2006.62

Tygel, D., \& Mota, E. (2010). Nova forma de gerir informação para uma nova economia. Nova Democracia, 45, 16-19.

Vranes, V., \& Vraneš, S. (2011). Applicability assessment of semantic web technologies. Information Processing \& Management, 47(4), 507-517. doi:10.1016/j.ipm.2010.11.002

Waters, J., Powers, B. J., \& Ceruti, M. G. (2009). Global interoperability using semantics, standards, science and technology (GIS3T). Computer Standards \& Interfaces, 31(6), 1158-1166. doi:10.1016/j.csi.2009.03.001

Zeng, M. L. (2010). Domain-specific markup languages and descriptive metadata: Their functions in scientific resource discovery. Encontros Bibli: Revista Eletrónica de Biblioteconomia e Ciência da Informação, 15(30). Retrieved from http://www.periodicos.ufsc.br/index.php/eb/ article/download/16890/15768
Zeng, M. L., \& Chan, L. M. (2006). Metadata interoperability and standardization -A study of methodology- Part II. D-Lib Magazine2, 12(6), 1082-9873.

\section{KEY TERMS AND DEFINITIONS}

Community: A formal or informal association of people that share the same goals and visions of a certain dimension of their lives.

Interoperability: The ability of different types of hardware and software to work together effectively, without prior communication, in order to exchange information in a useful and meaningful manner.

Metadata: Structured data that describes resources. This data explains, locates or makes it easy to recover, use and manage the described resources.

Networks: A set of social units and direct or indirect relations, with a common goal.

Semantic Web: A paradigm that implements a semantic interoperability that provides a common framework that puts machines sharing data, beyond community boundaries.

Social Solidarity Economy: An economy different from the market economy, where profit is not a goal. In Social and Solidarity Economy people associate in informal or formal groups and have common goals, these goals are neither centered in profit nor in individualistic needs.

Web Based Information Systems: Information systems based on the web technology.

\section{ENDNOTES}

$1 \quad$ See http://www.ica.coop/al-ica/_(Accessed October 10, 2011 - checked May 6, 2012)

2 Ministre délegué pour l'économie sociale

3 Ministre délégué pour l'économie sociale et solidaire Benoît Hamon 
$4 \quad$ These cooperative agendas are meetings specifically used for arranging collective commitments and conciliation of availabilities for meetings

$5 \quad$ See http://www.ripess.org (Accessed October 10, 2011 - checked May 6, 2012)

$6 \quad$ See http://scholar.google.com (Accessed June 26, 2011 - checked May 6, 2012)

7 See http://www.isiWebofknowledge.com (Accessed 26 June 2011 - checked May 6, 2012)

$8 \quad$ Seehttp://www.ndltd.org/serviceproviders/ scirus-etd-search (Accessed June 26, 2011 - checked May 6, 2012)

$9 \quad$ See http://www.scopus.com (Accessed 26 June 2011 - checked May 6, 2012)

10 Seehttp://oaister.worldcat.org (Accessed 26 June 2011 - checked May 6, 2012)

11 E-commerce web site

12 E-commerce web site

13 Exception for the Brazilians representatives.
14 Script available at http://www.maltas.org/ script.pdf (Accessed November 2, 2011 checked May 6, 2012)

15 See http://www.noosfero.org (Accessed October 10, 2011 - checked May 6, 2012)

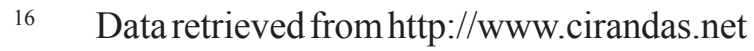
in 10 October.2011

17 Seehttp://www.eco-sapiens.com(Accessed October 10, 2011 - checked May 6, 2012)

18 Seehttp://www.fiess2011.org/en/(Accessed October 10, 2011 - checked May 6, 2012)

19 RDF stands for Resource Description Framework and it is a standard model for data interchange on the Web. For more information see http://www.w3.org/RDF/ (Accessed May 6, 2012)

20 The Semantic Web is a framework that allows data to be shared on the web. For more information see http://www.w3.org/2001/ sw/ (Accessed May 6, 2012) 